\title{
Phytoplankton biomass and species composition in relation to some physical and chemical characteristics of Lake Adale, Haramaya Woreda, Oromia Region, Ethiopia
}

\author{
Zelalem Dessalegn Fayissa
}

Adama Science and Technology University, School of Natural Sciences, Department of Biology, Adama, P.O.Box:1888, Ethiopia, e-mail: rabuma54@gmail.com

\begin{abstract}
Biomass and species composition of phytoplankton in relation to the physical and chemical conditions of the water in Lake Adale were studied from March, 2011 to September, 2011. All the physical, chemical and biological parameters measured varied temporally. The temperature of the lake was measured by digital oxygen meter and varied from $22^{\circ} \mathrm{C}$ to $26^{\circ} \mathrm{C}$. The chemistry of the lake was basically similar to the dilute East African lake waters, with maximum $\mathrm{pH}$ values of 9.2 as measured in situ by a portable digital pH meter. The inorganic nutrients, which were of moderately high levels, varied temporally as a function of hydrological, hydrographic and biological conditions of the lake and were measured by a Hach kit (DR/2000 spectrophotometer) for nitrate, and colorimetrically with the ascorbic acid method for phosphate and molybdosilicate method for silica. The phytoplankton community, which was consistently dominated by cyanobacteria, exhibited low species diversity. Phytoplankton biomass measured as chlorophyll $a$ varied from 23.35 to $55.18 \mathrm{mg} \mathrm{m}^{-3}$. The concentration of chlorophyll $a$ was calculated according to Talling and Driver (1963) using absorbance measurements made at 665 and $750 \mathrm{~nm}$. The biomass of the lake indicates that the lake is a productive one. The factors responsible for the observed temporal variations in the physical, chemical and biological features of the lake are discussed.
\end{abstract}

Key words: phytoplankton biomass, species, inorganic nutrients

\section{Introduction}

Rich natural resources that occur within the environment are characterized by having greater biodiversity. The availability and sustainable use of natural resources determines the food security situation of a country. In order to meet the growing food requirements of the world population, a great effort is necessary in the development and utilization of the biological wealth of the aquatic environment. Aquatic ecosystems have received attention as actual and potential sources of food. The exploitation of aquatic resources for human food involves a wide range of studies. The functioning of the phytoplankton community is also of both practical and theoretical interest. Comparative studies of several sets of variables suggested that the potential fish yield of an aquatic ecosystem might be related to several simple indicators of productivity (Henderson et al. 1973; Oglesby 1977; Melack 1976).
Phytoplanktons are the major primary producers in many aquatic systems and are an important food for consumers.

Lakes are one of humanity's most important resources, especially in the tropics, where they are often viewed as highly productive biological systems. They provide a number of functions. In spite of the fact that freshwater bodies are very limited and sensitive resources that need proper care and management, they are probably the most abused of resources. Tropical lakes, particularly those in Africa, are known for their high primary productivity of phytoplankton. The studies on phytoplankton photosynthesis in tropical Africa, particularly in East Africa, have come up with reports of exceptionally high photosynthetic activity. But, in Africa, human factors in combination with the natural conditions of climate and geology may influence water quality and quantity to a large extent. Ethiopia does not have the industry that flourished in the 
developed countries, and pollutants are not produced in large quantities. However, pollution resulting from human activities, such as land use and modification and other practices associated with rapid population increase, has caused or accelerated many changes in the lakes (Gebre-Mariam 1998). Fish production has become a victim of this decline in lake water levels. The decline damages the breeding grounds of fish species that spawn in shallower parts of the lake (e.g., Oreochromis niloticus, the most important species commercially). These effects are magnified in shallow lakes like Ziway, where a higher rate of water level fluctuation has been observed. Most of the Ethiopian lakes have not been adequately studied and Lake Adale is not an exception and there is very little information on the limnology of this lake. Without having basic information on the physical, chemical, and biological aspects of the lakes, it is difficult to evaluate and manage the living resources of the lake.

In this work, attempts were made to study the phytoplankton biomass and species composition in relation to some physical and chemical characteristics and biological properties of the Lake.

\section{Materials and Methods}

The sampling station of the present study was selected from the centre of Lake Adale. Water samples were collected once a month from the station. The samples collected were used to produce chemical analyses and measurement of biomass as chlorophyll $a$ concentration.

Measurement of physico-chemical parameters in the field. The parameters measured in-situ include the following: $\mathrm{pH}$ was measured in situ by a portable digital pH meter (Jenway 3200), and temperature was determined with a digital oxygen meter (Hanna 9024).

Analysis of inorganic nutrients. Water samples filtered through glass fibre filters (GF/C) were used for the analyses of Soluble Reactive Phosphate $\left(\mathrm{PO}_{4}-\mathrm{P}\right)$, Silica $\left(\mathrm{SiO}_{2}\right)$ and Nitrate $\left(\mathrm{NO}_{3}-\mathrm{N}\right)$. Nitrate-N was determined by using a Hach Kit (DR/2000 spectrophotometer). But, phosphate and silica were determined colorimetrically using the ascorbic acid and molybdosilicate methods (APHA 1999).

Measurement of biological parameters. Major species of phytoplankton preserved with Lugol's iodine found in samples collected on each sampling date were identified. The phytoplankton samples examined with a microscope and identification to genus or species level was made on the basis of various taxonomic literature available on phytoplankton (Whitford and Schumacher 1973; Jeji-Bai et al. 1977). Phytoplankton biomass was estimated as chlorophyll $a$ concentration spectrophotometrically from water samples filtered through glass filters (GF/C). Chlorophyll $a$ was extracted from the phytoplankton concentrate with aqueous acetone (90\%). The filters were manually ground with a glass rod to enhance extraction of pigments. The concentration of chlorophyll $a$ was calculated according to Talling and Driver (1963) using absorbance measurements made at 665 and $750 \mathrm{~nm}$.

\section{Description of the Study Area}

Lake Adale (300 ha) is located in Haramaya Wereda, East Harerghe Zone. Lake Adale is $26 \mathrm{~km}$ west of the city of Harar, and is to the north of the main Harar road with a latitude of $9^{\circ} 25^{\prime} 33^{\prime \prime} \mathrm{N}$ and longitude $41^{\circ} 57^{\prime} 03^{\prime \prime} \mathrm{E}$ (Fishpool and Evans 2001). The lake is surrounded by small hills and derives its water directly from rainfall and from several small streams that drain catchments to the west and north; floods from adjacent watersheds also occur (Fishpool and Evans 2001) (Fig.1).

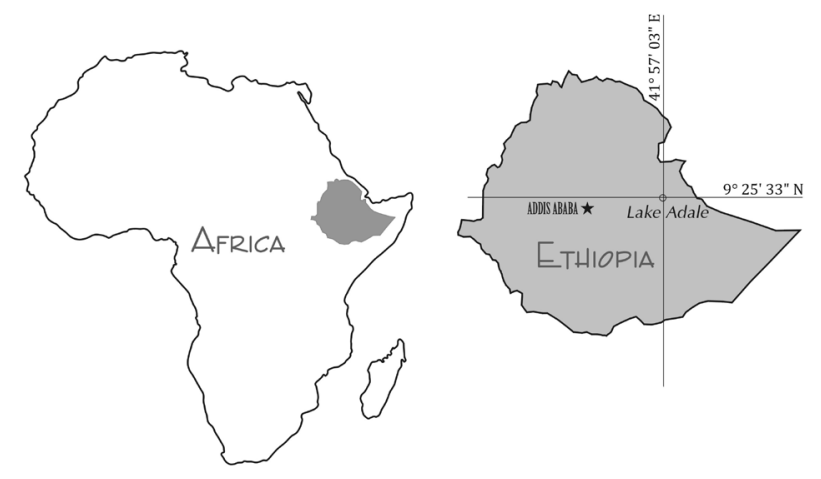

Fig.1. Location of Lake Adale, Ethiopia

\section{Results}

Physico-Chemical Features. The surface water temperatures at the central station of Lake Adale ranged from $22^{\circ} \mathrm{C}$ in March, 2011 to $26^{\circ} \mathrm{C}$ in July, 2011 . The $\mathrm{pH}$ of Lake Adale at the central station ranged from 8.7 in May 2011 to 9.2 in September, 2011. Concentrations of soluble reactive phosphate $\left(\mathrm{PO}_{4}-\mathrm{P}\right)$ re- 
corded in this study ranged from a minimum value of $11.67 \mu \mathrm{g} \mathrm{dm}^{-3}$ in August, 2011 to $67 \mu \mathrm{g} \mathrm{dm}^{-3}$ in June, 2011. Nitrate- $\mathrm{N}\left(\mathrm{NO}_{3}-\mathrm{N}\right)$ varied from $24 \mu \mathrm{g} \mathrm{dm}{ }^{-3}$ in April, 2011 to $35 \mu \mathrm{g} \mathrm{dm}^{-3}$ in the month of July, 2011. Molybdate reactive silica $\left(\mathrm{SiO}_{2}\right)$ also showed small temporal variations. The values recorded varied from a minimum of 7.4 in September, 2011 to a maximum of 13.2 in July, 2011 (Table 1).

Biological features. A total of 21 species of phytoplankton belonging to 6 classes were identified. The Phytoplankton biomass of Lake Adale exhibited temporal variations over the study period (Table 2 ).

\section{Discussion}

\section{Physico-Chemical Features}

As it was measured at the central station, the temperature of Lake Adale ranged from $22^{\circ} \mathrm{C}$ to $26^{\circ} \mathrm{C}$. The maximum surface water temperature of Lake
Adale is closer to those of Ethiopian Rift Valley Lakes including Lakes Ziway (18.5-27.5 ${ }^{\circ} \mathrm{C}$; Tilahun 1988), Abijata and Langano $\left(18-27^{\circ} \mathrm{C}\right.$; Kebede et al. 1994) and Awassa $\left(23.8-28.4^{\circ} \mathrm{C}\right.$; Kifle 1985), Lakes Kilole $\left(18.5-24^{\circ} \mathrm{C}\right.$; Lemma 1994$)$, Babogaya $\left(20.5-28.4^{\circ} \mathrm{C}\right.$; Major 2006) and the Legedadi Reservoir $\left(22.2-23.9^{\circ} \mathrm{C}\right.$; Sirage 2006). But it is less when compared with Lake Kuriftu, which ranged from a minimum of $22.8^{\circ} \mathrm{C}$ in February, 2006 to a maximum of $33.3^{\circ} \mathrm{C}$ in January, 2006 (Dessalegn 2007) Chamo $\left(26-30^{\circ} \mathrm{C}\right.$; Shumbulo 2004) in Ethiopia and Lake George, in Uganda (26$36^{\circ} \mathrm{C}$; Ganf and Horne 1975).

The $\mathrm{pH}$ of Lake Adale varied from 8.7-9.2, which indicates that the lake is a basic one. The recorded value is more or less similar to Lake Kuriftu with a minimum of 8.2 in August, 2005 to a maximum of 8.8 in November, 2005 (Desalegn, 2007), Lake Bishoftu (9.2; Gebre-Mariam 1994) and Babogaya (8.84-9.09; Major 2006) and the Rift Valley Lake

Table 1. Physical and inorganic nutrients of Lake Adale, 2011

\begin{tabular}{|c|c|c|c|c|c|c|c|}
\hline Parameter & March & April & May & June & July & August & September \\
\hline Temperature $\left({ }^{\circ} \mathrm{C}\right)$ & 22 & 23 & 25 & 24 & 26 & 23 & 23 \\
\hline $\mathrm{pH}$ & 8.9 & 8.8 & 8.7 & 8.9 & 9.0 & 9.0 & 9.2 \\
\hline $\mathrm{PO}_{4}-\mathrm{P}$ & 21.86 & 27.84 & 39.56 & 67 & 22.56 & 11.67 & 19.46 \\
\hline $\mathrm{NO}_{3}-\mathrm{N}$ & 31.38 & 24 & 26.65 & 29.5 & 35 & 32.63 & 26.75 \\
\hline $\mathrm{SiO}_{2}$ & 9.34 & 11.74 & 10.85 & 12.37 & 13.2 & 8.62 & 7.4 \\
\hline
\end{tabular}

Table 2. List of the major species of phytoplankton identified from Lake Adale, 2011

\begin{tabular}{ll}
\hline \multicolumn{1}{c}{ Phytoplankton group } & \multicolumn{1}{c}{ Species name } \\
\hline Cyanophyceae & Cylindrospermopsis africana Kom. and Kaling \\
Cyanobacteria & Planktolyngebya tallingii Kom. and Kaling \\
(Blue-green algae) & Planktolyngebya contorta (Lemm.)Anagn. and Kom. \\
& Microcystis aeruginosa Rab. \\
& Anabaena circinalis Rab. \\
& Psuedoanabaena sp. \\
& Raphidiopsis sp. \\
Chlorophyceae & Pediastrum simplex Meyen \\
(Green algae) & P. duplex Meyen \\
& Scenedesmus armatus Chod. \\
& Scenedesmus dimorphus (Turp.)Kutz. \\
& Scenedesmus quadricauda (Turp).Breb. \\
Bacillariophyceae & Chlamydomonas reticula \\
(Diatoms) & Thalassiosira sp. \\
& Nitzschia vermicularis(Kutz.)Grun. \\
\hline Dinophyceae(Dinoflagellates) & N. rostellate. \\
\hline Cryptophyceae(Cryptomonads) & Rhopahodia sp. \\
\hline Euglenophyceae & Peridinium sp. \\
(Euglenoids) & Cryptomonas obovata Skuja \\
\hline
\end{tabular}


Chamo (8.53-9.44; Shumbulo 2004). pH values which are remarkably different from those observed for Lake Adale were reported only from saline lakes, including Mariut in Egypt (Aleem and Samaan 1969) and Magaressa in Ethiopia (Talling et al. 1973), which have $\mathrm{pH}$ values between 9.0 and 10.5; these tend to remain at high levels owing to the high buffering capacity of the lake waters (Talling and Lemoalle 1998).

\section{Ambient Concentration of Inorganic Nutrients}

The soluble reactive phosphate of Lake Adale ranged from 11.67 to $67 \mu \mathrm{g} \mathrm{dm} \mathrm{dm}^{-3}$. This has similarity with Lake Kuriftu, in which it ranges from $8.64 \mu \mathrm{g}$ $\mathrm{dm}^{-3}$ in August, 2005 to a maximum of $41.5 \mu \mathrm{g} \mathrm{dm}{ }^{-3}$ in March, 2006 at the near-shore station, and from 10 in August, 2005 to $51 \mu \mathrm{g} \mathrm{dm}^{-3}$ in February, 2006 at the open station (Dessalegn 2007). The maximum level of soluble reactive phosphate (SRP) observed in Lake Adale is much lower than that reported for other crater lakes, that of Lakes Bishoftu $\left(280 \mu \mathrm{g} \mathrm{dm}^{-3}\right.$; GebreMariam 1994) and Magaressa (3200 $\mu \mathrm{g} \mathrm{dm}^{-3}$; Kebede et al. 1994) and the rift valley lakes Ziway (mean value of $90 \mu \mathrm{g} \mathrm{dm}^{-3}$; Beneberu 2005) and Lake Chamo (26.4$91.7 \mu \mathrm{g} \mathrm{dm}^{-3}$; Shumbulo 2004), but, it is higher than values recorded for another nearby crater lake Babogaya (1-11 $\mu \mathrm{g} \mathrm{dm}^{-3}$; Major 2006). The concentration of SRP recorded in the present study showed greater temporal variations which can be expected from the small size of the lake and the frequent occurrence of mixing. Most of the time phosphate concentrations were low on days of high phytoplankton biomass. The levels of nitrate determined in the present study in Lake Adale were from 24 to $35 \mu \mathrm{g} \mathrm{dm}^{-3}$. It was greater than Lake Babogaya (1-31 $\mu \mathrm{g} \mathrm{dm}^{-3}$; Major 2006) and Lake Awassa (7-20; Kebede and Belay 1994) but similar to Lake Bishoftu (25 $\mu \mathrm{g} \mathrm{dm}^{-3}$; Gebre-Mariam 1994), although they are still considerably lower than those of the rift valley lakes like Lake Ziway (28-136.5 $\mu \mathrm{g}$ $\mathrm{dm}^{-3}$; Tilahun 1988). The high nitrate concentrations at times coincided with relatively low phytoplankton biomass.

The value of molybdate reactive silica varied from 7.4 to $13.2 \mathrm{mg} \mathrm{dm}^{-3}$. The seasonal peaks in silica concentration were observed during the dry season suggesting the greater importance of autochthonous sources of silica. Although the observed concentrations of silica never approached that regarded as limiting to diatom growth (ca. $0.3 \mathrm{mg} \mathrm{dm}^{-3}$; Reynolds 1984), they are low in view of the high concentrations $(>10$ $\mathrm{mg} \mathrm{dm}^{-3}$ ) commonly encountered in African lakes
(Talling and Talling 1965; Talling 1995) including the nearby crater lakes Kilole (32; Prosser et al. 1968), Hora (55; Prosser et al. 1968) and Babogaya (10-58; Major 2006) and the Ethiopian Rift Valley lakes Ziway (45), Koka (32; Wood and Talling 1988) and Awassa (50-90; Kifle 1985).

\section{Species Composition and Abundance of Phytoplankton}

Table 2 presents a list of the major phytoplankton species identified during the study period. A total of 21 species of phytoplankton belonging to 6 classes were identified. The species composition and diversity of phytoplankton of Lake Adale were similar to those of Lake Babogaya (32; Major 2006) and Kuriftu (25; Dessalegn 2007). Phytoplankton diversity in Lake Adale (21 spp) is low when compared to those of the Ethiopian Rift Valley Lakes Ziway (67), Awassa (70) and Chamo 44) (Kebede and Willen 1998). Tilahun (2006) has also recently reported similarly high species diversity for Lakes Ziway, Awassa and Chamo in which the cyanobacteria were qualitatively and quantitatively important. Blue green algae, green algae and diatoms were the major algal (taxonomic) groups in terms of species richness and abundance. The other taxonomic groups - dinoflagellates; cryptomonads and euglenoids - were poorly represented. Microcystis aeruginosa was usually the most important in terms of abundance and formed the most conspicuous populations.

The blue-green algae, with seven species, were the most diverse and dominant taxonomic group. Green algae were the second in species richness in having six identified species. Diatoms were the third important taxonomic group with contributions of four identified species. Several studies have addressed phytoplankton composition and dynamics in large East African lakes and have provided a basis for understanding the ecology of algal communities (Descy et al. 2005). The persistence and dominance of cyanobacteria in Lake Adale is probably associated with fairly high levels of nutrients particularly phosphate and high temperature $\left(22\right.$ to $\left.26^{\circ} \mathrm{C}\right)$. Shapiro (1990) also suggested that high temperature helps the dominance of Cyanobacteria.

\section{Phytoplankton biomass}

The values recorded ranged from 23.58 in March, 2011 to 56.36 (mg Chl $a \mathrm{~m}^{-3}$ ) in July, 2011. The lowest phytoplankton biomass measured as $\mathrm{Chl} a$ was observed in May, 2011. This seasonal minimum Chl $a$ 
coincided with a period of precipitation resulting in land runoff that brought particulate materials into the lake with consequent reduction in light penetration. The maximum phytoplankton biomass value of Lake Adale is closer to those reported for Lakes Bishoftu (60; Gebre-Mariam and Taylor 1997), Lake Kuriftu (17.24-55.6; Dessalegn 2007), Ziway (22.9-57.5; Tilahun 2006) and Legedadi Reservoir (2.61-57.33 Sirage 2006). But it is higher than those observed for the nearby crater lake Babogaya (4-20; Major 2006), and Koka Reservoir (16; Kebede and Willén 1998). Much higher phytoplankton biomass values are known from a number of shallow East African lakes including Kilole and Magaressa in Ethiopia (382-412 and 195-880 $\mathrm{mg}$ Chl $a \mathrm{~m}^{-3}$; Talling et al. 1973).

Both phytoplankton biomass and all inorganic nutrients showed temporal variations. In tropical lakes, irradiance and temperature are probably not as frequently limiting as they are in temperate lakes (Lund 1964; Talling 1986; Talling and Lemoalle 1998) but nutrient availability as a function of hydrographic and hydrological conditions of the water body plays a major role in controlling the seasonal pattern of algal growth (Moss 1969; Talling 1986). In Lake Kuriftu, the correlations between biomass and the macronutrients nitrate-nitrogen $(\mathrm{r}=0.12)$ and phosphate (SRP) $(\mathrm{r}=0.14)$ were positive but weak while that between silica and biomass was relatively strong $(\mathrm{r}=0.691)$, although diatoms were not as important as the other algal groups in Lake Adale.

\section{Conclusion}

Lake Adale is a rather shallow, frequently mixing and productive lake. The lake exhibits temporal variations in phytoplankton biomass, physical characters and chemicals. These variations seem to be related to hydrological and hydrographic conditions of the lake, which in their turn determine the levels of nutrients. Variation in species composition of taxonomic groups of phytoplankton was observed. It was the blue-green algae of the genera Microcystis and Cylindrospermopsis which persistently dominated the phytoplankton community of the lake in species richness. The persistence of fairly high levels of nutrients, particularly phosphate, in a generally turbid and mixing water column favours the dominance of blue-greens.

\section{Acknowledgement}

I would like to thank the staff members of Haramaya University, School of Natural Sciences, Department of Biology and Mr.Sintayehu Workneh from the School of Agriculture, Department of Animal Science for their assistance during data collection and analyses. This study was financed by Haramaya University Young Science Faculty. So, I thank them for the financial support they have given to me.

\section{References}

Aleem A.A., Samaan A.A., 1969, Productivity of Lake Mariut, Egypt.Part II: Primary productivity, Int. Revue ges. Hydrobiol. 54(4): 491-527.

[APHA] American Public Health Association, 1999, Standard methods for the examination of water and waste water, APHA-AWWA-WEF, New York, p. 1325.

Beneberu G., 2005, Nutrient and plankton dynamics in the littoral and offshore zones of Lake Ziway [Master's Thesis], Addis Ababa University, Addis Ababa, p. 67.

Descy J.P., Hardy M.A., Stenuite S., Pirlot S., Leporcq B., Kimirei I., Sekadende B., Mwaitega R., Sinyenza D., 2005, Phytoplankton pigments and community composition in Lake Tanganyika, Freshwater Biol. 50: 668-684.

Dessalegn Z., 2007, Temporal dynamic of phytoplankton biomass and species composition in relation to some physico-chemical characterstics of Lake Kuriftu, Ethiopia [Master's Thesis], School of Graduate Studies, Addis Ababa University, Addis Ababa. p. 90.

Fishpool L.D.C., Evans M.I. (eds), 2001, Important Bird Areas in Africa and Associated Islands: Priority Sites for Conservation. Birdlife Conservation Series No. 11, Pisces Publications \& BirdLife International, NewburyCambridge, p. 1144.

Ganf G.G., Horne A.J., 1975, Diurnal stratification, photosynthesis and nitrogen fixation in a shallow equatorial lake (Lake George, Uganda), Freshwater Biol. 5(1): 1339.

Gebre-Mariam Z., 1994, Long-term changes in indices of chemical and productive status of a group of tropical Ethiopian lakes with differing exposure to human influences, Arch. Hydrobiol. 132: 115-125.

Gebre-Mariam Z., 1998, Human Interactions and water Quality in the Horn of Africa, Proc. of the Symposium Science in Africa: Emerging Water Management Issues, Philadelphia: 47-61.

Gebre-Mariam Z., Taylor W.D., 1997, Bacteria-chlorophyll relationships in Ethiopian lakes of varying salinity: are soda lakes different?, J. Plankton Res. 19: 647-654.

Henderson H.F., Ryder R.A., Kudhogina A.W., 1973, Assessing fishery potentials of lakes and reservoirs, J. Fish. Board Cand. 30: 2000-2009. 
Jeeji-Bai N., Hegewald E., Soeder C. J., 1977, Revision and taxonomic analysis of the genus Anabaenopsis, Arch. Hydrobiol. 51: 3-24.

Kebede E., Belay A., 1994, Species composition and phytoplankton biomass in a tropical African lake (Lake Awassa, Ethiopia), Hydrobiologia 288: 3-32.

Kebede E., Teferra. G., Taylor W.D., Gebre-Mariam Z., 1994, Eutrophication of Lake Hayq in the Ethiopian highlands, J. Plankton Res. 14(10): 1473-1482.

Kebede E., Willén E., 1998, Phytoplankton in a salinity-alkalinity series of lakes in the Ethiopian Rift Valley, Algol. Stud. 89: 63-96.

Kifle D., 1985, Variation in phytoplankton primary production in relation to light and nutrients in Lake Awassa [Master's Thesis], Addis Ababa University, Addis Ababa, p. 108.

Lemma B., 1994, Changes in the limnological behavior of a tropical African explosion crater lake: L. Hora-Kilole, Ethiopia, Limnologica 24(1): 57-70.

Lund J.W.G., 1964, Primary productivity and periodicity of phytoplankton, Int. Ver. Theor. Angew. Limnol. Verh. 15: 37-56.

Major Y., 2006, Temporal changes in the community structure and photosynthetic production of phytoplankton in Lake Babogaya, Ethiopia [Master's Thesis], School of Graduate Studies, Addis Ababa University, Addis Ababa. p. 94.

Melack J.M., 1976, Limnology and dynamics of phytoplankton in equatorial African lakes [Dissertation], Duke University, Durham, p. 453.

Moss B., 1969, Limitation of algal growth in some central African waters, Limnol. Oceanogr. 14: 591-601.

Oglesby R.T., 1977, Relationship of fish yield to lake phytoplankton standing crop, production and morphoedaphic factors, J. Fish. Res. Bd, Can. 34: 2271-2279.

Prosser M.V., Wood R.B., Baxter R.M., 1968, The Bishoftu crater lakes: A bathymetric and chemical study, Arch. Hydrobiol. 65: 309-324.

Reynolds C.S., 1984, The ecology of fresh water phytoplankton, Cambridge University Press, Cambridge, p. 384.

Shapiro J., 1990, Biomanipulation: the next phase making it stable,Hydrobiologia 200:13-27.
Shumbulo E., 2004, The temporal and spatial variations in the biomass and photosynthetic production of phytoplankton in relation to some physico-chemical variables in Lake Chamo Ethiopia [Master's Thesis], Addis Ababa University, Addis Ababa, p. 72.

Sirage A., 2006, Water quality and phytoplankton dynamics in Legedadi Reservoir [Master's Thesis], Addis Ababa University, Addis Ababa, p. 109.

Talling J.F., 1986, The seasonality of phytoplankton in African lakes, Hydrobiologia 138:139-160.

Talling J.F., 1995, The Photosynthetic activity of Phytoplankton in East African lakes, Int. Rev. ges. Hydrobiol. 50: 1-32.

Talling J.F., Driver D., 1963, Some problems in estimation of Terrestrial algae: The British Physiological Society, Cambridge Taxonomic analysis of the genus Anabaenopsis, Arch. Hydrobiol. 51: 3-24.

Talling J.F., Lemoalle J., 1998, Ecological dynamics of tropical inland waters, Cambridge University Press, Cambridge, p. 441.

Talling J.F., Talling I.B., 1965, The chemical composition of African lake waters, Int. Rev. ges. Hydrobiol. 50: 421-463.

Talling J.F., Wood R.B., Prosser M.V., Baxter R.M., 1973, The upper limit of photosynthetic productivity by phytoplankton: Evidence from Ethiopian soda lakes, Freshwater Biol. 3: 53-76.

Thornton J.A., 1987, A review of some unique aspects of the limnology of shallow Southern African man-made lakes, GeoJournal 143: 339- 352.

Tilahun G., 1988, A seasonal study on primary production in relation to light and nutrients in Lake Ziway, Ethiopia [Master's Thesis], Addis Ababa University, Addis Ababa, p. 62.

Tilahun G., 2006, Temporal dynamics of the species composition, abundance and size-fractionated biomass and primary production of Phytoplankton in Lakes Ziway, Awassa and Chamo (Ethiopia) [Dissertation], Addis Ababa University, Addis Ababa, p. 201.

Whitford L.A., Schumacher G.J., 1973, A manual of freshwater algae, Sparks Press, Raleigh, p. 324.

Wood R.B., Talling J.F., 1988, Chemical and algal relationship in a salinity series of Ethiopian inland waters, Hydrobiologia 158: 29-67. 